\title{
O novo paradigma da gestão pública e a busca da accountability democrática
}

Robert D. Behn

\section{Introdução}

Os campeões da nova gestão pública têm desafiado o paradigma tradicional da administração pública, que regulou nosso pensamento e deliberações (se não nossa prática) por mais de um século. $\mathrm{O}$ argumento deles é bastante simples: o método tradicional de organização do poder executivo é muito lento, burocrático, ineficiente, pouco responsivo, improdutivo. Ele não nos dá os resultados que esperamos de um governo. E atualmente, cidadãos esperam que um governo produza resultados. Eles não toleram mais a ineficiência ou a ineficácia. Portanto, precisamos de uma nova forma de trabalhar, um novo paradigma de gestão governamental. ${ }^{1}$

Mas esperem, respondem os defensores do paradigma tradicional da administração pública. Nossa abordagem de trabalho com o governo pode ter algumas deficiências, mas ela também tem uma enorme vantagem: tem accountability perante os cidadãos. A accountability democrática não é opcional; ela é uma característica essencial de qualquer abordagem para a estruturação do poder executivo. Não importa que o paradigma de vocês aplique-se bem às organizações do setor privado. Com o governo é diferente. Governos devem ser responsáveis, não só perante alguns poucos stakeholders interessados, mas sim ante todo o Estado. Se seu sistema não assegura accountability perante os cidadãos, então ele é, por definição, inaceitável. ${ }^{2}$

Tal provocação não pode ser ignorada. Os defensores da abordagem da nova gestão pública devem agora não apenas demonstrar que sua estratégia é mais eficiente e eficaz. Eles devem também provar que ela é

Professor e Diretor do Governors Center e professor do Terry Santerd Institute of Public Policy, ambos da Universidade de Duke, Carolina do Norte, EUA 
politicamente responsável. Aqueles que buscam criar um novo paradigma de gestão pública terão o ônus de apresentar um conceito correlato de accountability democrática.

\section{O paradigma da administração pública e o problema da corrupção}

No final do século XIX, o paradigma da administração pública evoluiu em resposta à corrupção que havia invadido o governo norte-americano. Em seu famoso ensaio de 1887 sobre $O$ Estudo da Administração, Woodrow Wilson observou que os americanos tinham "acabado de começar a sanear um serviço público que já estava podre há 50 anos”. Além disso, ele relacionou diretamente a eliminação da corrupção com a introdução de uma administração eficaz: "A atmosfera venenosa do governo municipal, os segredos fraudulentos da administração estatal, a confusão, os benefícios e a corrupção constantemente descobertos nos gabinetes de Washington, proíbem-nos de acreditar que quaisquer concepções claras do que constitui uma boa administração sejam, até o momento, comuns nos Estados Unidos". Dessa forma, Wilson defendeu uma nova abordagem para a tarefa da administração governamental: "Por essa razão deve haver uma ciência da administração, que busque endireitar os caminhos do governo, tornar seus negócios mais parecidos com negócios privados, fortalecer e purificar sua organização, e coroar sua diligência" (1887: 13-6).

De muitas formas, o paradigma da administração pública solucionou o problema da corrupção. Ao separar a implementação das políticas públicas das decisões políticas que as criam, tal como Wilson recomendara, os defensores da nova administração pública buscavam proteger as políticas do favoritismo e do ganho individual, que se intrometiam nas decisões administrativas sobre pessoal, suprimentos, finanças e prestação de serviços. Como resultado, nesse século, o governo dos Estados Unidos comportou-se de forma muito menos corrupta do que no século anterior. Obviamente, o governo no século XX não tem sido completamente livre de corrupção; mas sempre que ocorressem abusos ao poder público, isso poderia ser atribuído a um colapso de um dos princípios básicos do paradigma da administração pública - em especial do princípio da separação entre administração e política.

\subsection{O paradigma da gestão pública e a questão do desempenho}

No final do século XX, porém, o governo americano está menos infestado pelo problema da corrupção do que pela questão do desempenho. 
O governo americano pode não ser muito fraudulento; mas também não é tão eficaz. A resposta tem sido o que alguns chamam de nova gestão pública com ênfase na produção de resultados.

Em muitos pontos, o paradigma da gestão pública é uma resposta direta às inadequações do paradigma da administração pública, particularmente àquelas da burocracia. Na nova gestão pública, os servidores públicos não são autômatos, simplesmente implementando políticas segundo regras promulgadas por alguns superiores. Ao contrário, o paradigma da nova gestão pública pressupõe que servidores públicos sejam inteligentes, compreendam os problemas de suas agências com a redução dos quadros, tenham algumas idéias úteis - tanto próprias quanto emprestadas de outros - sobre como solucionar tais problemas, e que possam, se tiverem liberdade para tal, transformar rapidamente tais idéias em ações eficazes. De fato, o paradigma da gestão pública pressupõe que, como os servidores públicos na linha de frente estão mais próximos dos problemas, eles estão em excelente posição (talvez a melhor) de decidir que abordagem tomar para solucionar os problemas públicos.

Os defensores da nova gestão pública não pretendem que a administração possa ser desligada do Estado ou da política. Eles aceitam o fato como tal e buscam explorar essa realidade bem conhecida, mas cuidadosamente evitada. Portanto, sob o paradigma da gestão pública, servidores públicos são investidos de poder para tomar decisões. Eles são instruídos a responder aos cidadãos individualmente e encorajados a desenvolver abordagens novas e inovadoras para solucionar problemas públicos.

Tais defensores da nova gestão pública desprezam o paradigma da administração pública. Eles rejeitam a idéia de que a política deva (ou possa) ser separada da administração — que a mente do servidor público deva desligar-se da solução dos problemas políticos. Eles olham com escárnio o ideal burocrático que tenta basear a implementação de políticas em regras impessoais. No entanto, ironicamente, eles não rejeitam completamente a gestão científica; mas preferem, ao invés de buscar 'o melhor caminho', procurar pela 'melhor prática' ${ }^{3}$ dos dias atuais.

Os defensores do paradigma da gestão pública ainda estão tentando solucionar o problema da desempenho. Para eles, o controle da corrupção é um desafio muito menor do governo atual do que a produção de resultados. Conseqüentemente, eles não estão tão preocupados em descartar algumas das salvaguardas da administração pública que ajudaram a eliminar (e continuam a prevenir) a corrupção. $\mathrm{O}$ mais significativo é que eles também não se preocupam em combinar seu novo paradigma de desempenho com os conceitos existentes - ou mesmo os novos — de accountability política. Nem sequer incomodam-se em construir um novo paradigma de accountability democrática. 


\section{Wilson, Taylor e Weber: o paradigma da administração pública}

A herança intelectual do atual paradigma da administração pública decorre do pensamento, escritos e proselitismo de Woodrow Wilson, Frederick Winslow Taylor e Max Weber. De fato, os três construíram a base conceitual da atual forma da maioria dos nossos governos. Wilson afirmava que a administração deveria — e poderia — ser separada da política; depois que os responsáveis pelas políticas tomassem as decisões de Estado, a tarefa de implementar tais políticas podia ser delegada àqueles bem versados na 'ciência da administração', que executariam a tarefa da implementação da forma mais eficiente possível (1887). Isso seria possível porque, segundo afirmava Taylor, "entre os vários métodos e implementos utilizados em cada elemento de cada caso, existe sempre um método e um implemento mais ágil e melhor que todos os outros" (1911:25). Finalmente, Weber afirmava que a burocracia era o mais eficiente mecanismo organizacional; assim, a burocracia seria ideal para implementar os princípios científicos de Taylor. ${ }^{4}$

Todos eles, Wilson, Taylor e Weber, buscavam melhorar a eficiência. E além se ser um valor em si mesmo, a eficiência tem outra vantagem. Ela é impessoal, e portanto justa. Ao separar a administração das políticas, aplicando o exame científico ao desenho do melhor processo de trabalho, e empregando organizações burocráticas para implementar esses processos, o governo garantiria não só que as políticas fossem justas, mas que sua implementação também o fosse ${ }^{5}$. E, claro, a administração do governo dos Estados Unidos da América tinha de ser justa.

A ênfase na eficiência tem outra vantagem: ela implica em que a implementação da política pode, de fato, ser separada das decisões políticas. E se há, de fato, uma maneira eficiente de implementar qualquer política, e uma forma ideal de executar qualquer decisão política, então separar a administração da política é razoavelmente factível.

Além disso, a separação entre administração e política permite que o processo governamental esteja conceitualizado de forma clara e linear: as pessoas elegem seus representantes legislativos e chefes do executivo; tais indivíduos (e seus assistentes políticos imediatos) desempenham a tarefa política de desenvolver e decidir sobre as políticas públicas; a seguir, o aparato administrativo do governo determina a forma mais eficiente de implementar cada política e assim o faz; e finalmente, caso algo dê errado, as autoridades eleitas verificam o trabalho dos administradores.

Conceitualizar o processo do governo dessa maneira também fornece um método claro, simples e direto de accountability democrática. Como a administração pode ser separada da política, e visto que o aparato 
burocrático do governo encontrará e escolherá o modo mais eficiente de implementar qualquer política, o público não precisa se preocupar com a administração. Tudo com o que os cidadãos devem preocupar-se é com a política. E se eles não gostarem das políticas do governo (ou de como a sua administração está sendo vista), eles têm meios diretos e eficazes de corrigir a situação: numa eleição, eles podem retirar as autoridades dos gabinetes. Isso é accountability política. Isso é accountability direta ${ }^{6}$.

O paradigma da administração pública tem sentido - ele é internamente consistente - porque a distinção entre política e administração permite a construção de um modelo simples, atraente e direto de accountability política. Além disso, com todas as suas falhas, o antigo paradigma tem uma vantagem significativa: legitimidade política. As relações de accountability política são transparentes. O paradigma tradicional da administração pública combina-se bem com nosso paradigma tradicional de accountability democrática.

\subsection{A distinção de Wilson entre política e administração}

Em seu $O$ estudo da administração, Woodrow Wilson definiu a distinção entre política e administração. "Administração pública é a execução detalhada e sistemática da lei pública", declarou Wilson. "O campo da administração é o campo dos negócios. Ele é desprovido da pressa e da luta da política". De fato, Wilson escreveu sobre a "verdade"de que "a administração repousa fora da esfera própria da política. Questões administrativas não são questões políticas" (1887: 18-9).

Wilson descreveu sua distinção entre política e administração de vários modos: "a distinção se dá entre planos gerais e meios específicos". "Os vastos planos da ação governamental não são administrativos; a execução detalhada de tais planos é que é administrativa". Wilson sequer tentou definir a distinção de modo muito preciso pois, para ele, "essa discriminação entre administração e política é hoje, felizmente, bastante óbvia para demandar qualquer discussão" (1887: 18-9) ${ }^{7}$.

Em 1881, o presidente Garfield foi assassinado por um funcionário desapontado e, dois anos mais tarde, o Congresso aprovou o Pendleton Act para reformar o serviço público federal. Portanto, quando Wilson escrevia, em 1887, tinha muito da reforma do serviço público em mente. Para Wilson, "é por uma necessidade puramente de negócios" que o governo americano possui "um corpo de oficiais cuidadosamente treinados, servindo durante um período de bom comportamento". Isso, é claro, traz à tona a seguinte questão: “em que constitui o bom comportamento?", à qual Wilson respondeu com sua própria definição do que hoje costuma-se chamar "competência neutra": todos os servidores públicos devem ter uma "submissão firme, inerente à política do governo que eles servem". 
Além do mais, tal política "não será a criação de autoridades permanentes, mas de homens de Estado cuja responsabilidade perante a opinião pública será direta e inevitável". Portanto, concluía Wilson, a reforma do serviço público "está realizando uma limpeza na atmosfera moral da vida oficial, ao estabelecer a santidade do gabinete público como uma confiança pública; e ao tornar o serviço apartidário, está abrindo caminho para aproximá-lo do mundo dos negócios" (1887: 18-2, 21).

De fato, a ciência eminentemente prática da administração defendida por Wilson estava designada a fazer mais do que fornecer orientação para estruturar o serviço público: "é praticamente um pressuposto básico para todos nós, que o movimento atual, chamado reforma do serviço público, deva, após a concretização de seu primeiro propósito, expandir-se em esforços para aperfeiçoar não somente o pessoal mas também a organização e os métodos das nossas autoridades de governo, visto que é óbvio que sua organização e métodos necessitam ser aperfeiçoados tanto quanto seu pessoal. Estamos no momento corrigindo os métodos de seleção; deveremos avançar até ajustarmos as funções executivas de modo mais saudável e receitar melhores métodos para a organização e ação executivas" (1887: 11-8).

Além disso, para Wilson, "o objetivo do estudo da administração é o libertar os métodos executivos dos métodos confusos e custosos da experiência empírica e erguê-los sobre bases firmemente enraizadas em um princípio estável". Dessa forma, quase 25 anos antes das idéias de Frederick Taylor terem ficado famosas, quando a Comissão Interestadual de Comércio, em 1910, realizou audiências sobre as tarifas ferroviárias, Wilson já tinha defendido o princípio que Louis Brandeis classificara, durante tais audiências, de "gestão científica". Wilson escreveu a respeito de "uma ciência da administração" e preocupou-se com o fato de que "poucos métodos científicos imparciais podem ser discernidos na nossa prática administrativa [americana]" (1887: 13-8). Realmente, uma das características mais proeminentes da escola política de Wilson, segundo Neils Thorsen, era "uma convicção amadurecida de que o conhecimento científico das práticas econômicas, políticas e administrativas podia ser introduzido na conduta governamental" (1988:10-1).

$\mathrm{Na}$ busca de tal conhecimento, Wilson esperava que a Europa fornecesse modelos de administração governamental. Para aqueles que pudessem "amedrontar-se com a idéia de analisar sistemas administrativos estrangeiros para instrução e sugestão", Wilson enfatizava a distinção entre os fins puramente norte-americanos e a adaptação de meios úteis europeus. Wilson estava interessado unicamente em "estudar administração como forma de pôr em prática, convenientemente, nossas próprias políticas”. Para provar seu ponto de vista, ele lançou mão da 
seguinte metáfora: "se eu observar um assassino afiar sua faca de maneira sábia, eu posso aprender seu modo de amolar lâminas sem adquirir sua provável intenção de cometer um assassinato com ela; portanto, se eu observar um monarquista empoado administrando bem um escritório público, eu posso aprender seus métodos de trabalho sem alterar minhas visões republicanas. Ele pode servir ao seu rei; eu continuarei a servir ao povo; mas eu gostaria de servir ao meu soberano tão bem quanto ele o faz".

Qualquer que fosse o modelo administrativo encontrado na Europa, Wilson enfatizava que ele deveria ser adaptado à forma do governo federal dos Estados Unidos: “devemos americanizá-lo" (1887: 13-4; 23).

\subsection{A gestão científica de Taylor}

Frederick Winslow Taylor pregava uma variedade de mudanças uma revolução mental completa; uma grande revolução mental (Wrege e Greenwood, 1991: 191) — na forma em que a nação deveria organizar seus locais de trabalho. Ele preocupava-se com "a grande perda que todo o país sofre em virtude da ineficiência em quase todas as nossas ações diárias" e estava convencido de que "o remédio para toda essa ineficiência reside na gestão sistemática, e não na busca de um homem incomum ou extraordinário". No cerne do pensamento de Taylor estava sua crença de que "em cada elemento do mercado existe sempre um método e uma implementação que é mais rápido e melhor que qualquer outro"(1991: 7-25).

A ineficiência que Taylor encontrara havia sido criada pelo uso de métodos como "na falta de regras, improvise" e "sempre se fez assim" que os empregados utilizavam ao desenvolver suas atividades. Isso, no entanto, não era culpa deles. Resultava, ao contrário, dos velhos sistemas de gestão em uso que davam a cada trabalhador "a responsabilidade final de realizar suas tarefas praticamente da forma que eles julgassem melhor, com pouca ajuda e aconselhamento da gerência". Taylor queria que a gerência assumisse a tarefa de desenhar o fluxo de trabalho. Ele queria que a gerência - especificamente o Departamento de Planejamento - determinasse cientificamente qual componente do trabalho poderia ser executado de maneira mais eficiente, particularmente por um funcionário "de primeira classe", que estivesse cientificamente preparado para a tarefa $(1911: 16 ; 25 ; 32)^{8}$.

A respeito de gerência científica, Taylor escreveu:

Os gerentes assumem cargas de trabalho adicionais e responsabilidades jamais pensadas no passado. Os gerentes assumem, por exemplo, a carga de recolher e organizar todo o conhecimento tradicional que no passado fora possuído pelos trabalhadores, além de classificar, tabular e 
reduzir esse conhecimento a regras, leis e fórmulas que serão imensamente úteis aos trabalhadores no cumprimento de suas tarefas diárias.

Em particular, Taylor acreditava que os gerentes de qualquer empresa possuíam quatro "novos deveres":

a) eles desenvolveriam a ciência de cada elemento do trabalho humano, que substituiria o antigo método da improvisação;

b) eles selecionariam cientificamente e depois treinariam, ensinariam e capacitariam cada trabalhador, enquanto que no passado cada um escolhia seu próprio trabalho e treinava-se o melhor que pudesse;

c) eles cooperariam de maneira dedicada e cordial com os trabalhadores para assegurarem-se de que todo o trabalho estaria sendo feito de acordo com os princípios da ciência desenvolvida;

d) existiria uma divisão praticamente igual de trabalho e responsabilidade entre os gerentes e os trabalhadores. A gerência assumiria [sic] todo o trabalho para o qual ela estivesse melhor preparada que os trabalhadores, enquanto no passado quase todo o trabalho e grande parte da responsabilidade eram depositados nos ombros dos trabalhadores.

Essas são responsabilidades da gerência, argumentava Taylor, porque os trabalhadores não têm tempo de pensar no melhor sistema de trabalho e também de trabalhar. Pois mesmo "caso o trabalhador esteja bem preparado para desenvolver e utilizar dados científicos, seria fisicamente impossível para ele trabalhar numa máquina e numa escrivaninha ao mesmo tempo". Além do mais, continuava Taylor, "também é claro que na maioria dos casos, é necessário um tipo de homem para planejar adiante, e um tipo completamente diferente para executar o trabalho" (1911: 36-8).

Taylor organizava o trabalho em torno do conceito de "tarefa" - a qual ele chamava de "talvez o elemento único mais proeminente da gerência científica moderna". A tarefa "especifica não só o que deve ser feito, mas como deve ser feito e o tempo exato permitido para que seja feito". E o trabalho de definir cada uma das tarefas é responsabilidade da gerência: "o trabalho de cada homem é totalmente planejado pela gerência, com pelo menos um dia de antecedência, e cada homem recebe, na maioria dos casos, instruções completas por escrito, que não só descrevem em detalhe a tarefa que ele deve executar, como também os meios a serem utilizados durante o trabalho". Para Taylor, "gerência científica" era uma "tarefa da gerência" (1911: 39).

Além disso, a gerência tem a responsabilidade de encaixar as pessoas nos trabalhos para os quais elas são melhor qualificadas. Essa era a definição de "homem de primeira classe" — alguém que estava cientificamente preparado para o trabalho. E, apesar de haverem pessoas de segunda classe em alguns trabalhos, todos seriam "de primeira classe" para algum trabalho. "Eu tentei", disse Taylor na Câmara dos Deputados americana, "deixar claro que, para cada tipo 
de trabalhador, pode ser encontrado um trabalho para o qual ele é "de primeira classe", com a exceção daqueles homens que estariam perfeitamente qualificados para um trabalho, mas que não o realizarão" (Wrege e Greenwood, 1911: 194).

O conceito de Taylor sobre tarefa e sua abordagem sobre cada tarefa individual — reflete-se nas "descrições de tarefas" " do nosso sistema do serviço público. Pois no governo, é responsabilidade da gerência (e não do trabalhador) definir cada tarefa que cada trabalhador deve desempenhar. Tais tarefas estão listadas na descrição de tarefas, e a gerência preenche cada posto vago pela seleção científica do indivíduo cujas qualificações mais se assemelham ao perfil da referida descrição. A responsabilidade do trabalhador é de executar tais tarefas - e somente essas tarefas. Trabalhadores não devem pensar sobre tais tarefas; isso é estritamente trabalho da gerência. Os sistemas do serviço público aplicam o conceito de Taylor de gerência científica, o qual "envolve o estabelecimento de várias regras, leis e fórmulas que substituem o julgamento do indivíduo trabalhador" (1911: 37).

Taylor argumentava que seus quatro deveres tarefas "podem ser aplicados a absolutamente todas as classes de trabalho, do mais elementar ao mais intrincado". Além do mais, ele afirmava que "quando eles são aplicados, os resultados devem ser incrivelmente maiores do que aqueles que se pode atribuir ao estilo de gerência de iniciativa e incentivo". Na verdade, Taylor foi ainda mais longe: "a adoção geral da gerência científica dobraria, no futuro, a produtividade do homem médio envolvido com o trabalho industrial". E apesar de Taylor ter feito todo o seu trabalho em esferas industriais, ele acreditava claramente que seus princípios podiam ser aplicados à gerência de várias instituições, inclusive de igrejas, universidades e de repartições governamentais $(1911: 8 ; 40 ; 142)$.

\subsection{A burocracia de Weber}

À medida que a sociedade torna-se mais complexa, afirmava Max Weber, ela necessita de instituições mais complexas. Para Weber, isso significava um salto de organizações informais, pessoais, para a burocracia. A burocracia de Weber distinguia-se por ser uma organização hierárquica, onde trabalhavam pessoas indicadas, com credenciais e especialidades, que teriam obrigações regulares e oficiais, que elas executavam como se fossem "curadores", aplicando regras racionais de forma impessoal, sobre uma jurisdição específica. No governo, dizia Weber, isso era chamado "autoridade burocrática", ao passo que no setor privado era chamado "gerência burocrática" (1946: 81). ${ }^{10}$

"O princípio da autoridade hierárquica do escritório", escreveu Weber, "é encontrado em todas as estruturas burocráticas: no Estado e 
nas estruturas eclesiásticas, e também em grandes organizações de partidos [políticos] e empresas privadas". De fato, ele afirmava, "não interessa ao caráter da burocracia se sua autoridade é "privada ou pública". A hierarquia ainda é o princípio organizador, e esse "escritório hierarquizado é organizado monocraticamente". Weber escreveu especificamente que "os princípios da hierarquia do escritório e dos níveis de autoridade graduada significam um sistema firmemente ordenado, onde os níveis mais baixos são supervisionados pelos mais altos" (1946: 81-2).

As pessoas que trabalham nas várias posições nessa hierarquia adquirem credenciais educacionais, são nomeadas, desenvolvem suas especialidades, e concordam em executar suas obrigações de forma leal, mas impessoal. "A gerência de escritório, ou ao menos a gerência do escritório especializado", disse Weber, "geralmente pressupõe um treinamento detalhado e especializado". Ao aceitar uma posição na burocracia, ele continua, um indivíduo aceita "uma obrigação específica de realizar uma gerência fiel, em troca de uma existência segura". Esse indivíduo não é leal a seu chefe como pessoa, mas à posição de seu chefe; o que significa que "a lealdade moderna é devotada a propósitos impessoais e funcionais" (1946, 82-83).

Para Weber, a burocracia comporta-se como um juiz de posse de um computador: "a burocracia é como um juiz moderno, que por sua vez é como uma máquina de vender doces, que recebe as solicitações junto com o pagamento e a seguir libera o julgamento juntamente com as razões derivadas mecanicamente do código" (Bendix, 1960:421). A burocracia de Weber - com ênfase na implementação impessoal por meio de regulamentos racionais - era ao mesmo tempo eficiente e justa:

"A experiência tende, universalmente, a mostrar que a organização burocrática de tipo puramente administrativo — isto é, a burocracia de variedade monocrática — é, do ponto de vista puramente técnico, capaz de atingir o mais alto grau de eficiência e, nesse sentido, é formalmente o meio racional mais conhecido de executar o controle imperativo sobre os seres humanos. Ela é superior a qualquer outra forma em termos de precisão, estabilidade, rigor de sua disciplina, e confiabilidade... Ela é finalmente superior tanto na sua eficiência intensiva e no escopo de suas operações, e é formalmente capaz de aplicar todos os tipos de tarefas administrativas" (Weber, 1947: 337).

No entanto, a interferência da política pode ameaçar a burocracia, tanto em sua eficiência como na sua capacidade de justiça.

$\mathrm{Na}$ verdade, reconheceu Weber, a corrupção política pode interferir no trabalho dos especialistas nomeados impessoalmente de acordo 
com as regras. Embora Weber acreditasse que as burocracias eficazes

seriam um benefício para os políticos que buscassem a reeleição, ele também reconheceu que esse não seria sempre o caso:

"Quando a demanda pela administração dos especialistas treinados for considerável, e os seguidores do partido tiverem de reconhecer uma "opinião pública" intelectualmente desenvolvida, educada e com movimentos livres, o uso de pessoal desqualificado cairá nas mãos do partido no poder na eleição seguinte... A demanda pela administração treinada existe atualmente nos Estados Unidos, mas nas maiores cidades, onde os votos dos imigrantes são "votos de curral", a opinião pública educada é, certamente, inexistente. Portanto, as eleições populares do chefe administrativo e dos oficiais subordinados ameaçam geralmente a qualificação do pessoal, como também o funcionamento preciso do mecanismo burocrático" (1946: 85).

Portanto, para garantir tanto a eficiência quanto a justiça, Weber, como Wilson, buscou separar a política da administração.

\section{A falácia da administração eficiente e apolítica}

Infelizmente, o paradigma da administração pública não se demonstrou nem eficiente nem apolítico como previam os escritos de Wilson, Taylor e Weber. De fato, ele é muito ineficiente e bastante político. A lógica de cada um dos fundadores intelectuais do paradigma da administração pública foi contaminada pela falácia crítica.

\subsection{A falácia de Weber: burocracias são burocráticas}

A burocracia é eficiente? Atualmente pensamos que não. Na realidade, o termo burocracia hoje é, no vernáculo, sinônimo de ineficiência.

Uma das características da burocracia é a especialização das tarefas. E a base conceitual dessa especialização é sua eficiência. Visto que indivíduos diferentes especializam-se em realizar distintas tarefas, cada indivíduo terá domínio somente de sua tarefa. Não é preciso que as pessoas de toda a burocracia saibam como realizar todas as tarefas; elas nem ao menos necessitam entender tais tarefas individuais ou como elas se relacionam e se complementam. Ao contrário, cada um pode concentrar-se em realizar a sua própria tarefa muito bem.

Infelizmente, dividir o trabalho de uma burocracia em tarefas distintas e especializadas cria um problema novo: a coordenação. Se todos executam todas as tarefas, eles podem coordená-las em seus cérebros, 
separadamente; não existe problema de coordenação. Mas quando todas as tarefas são divididas, a coordenação torna-se um fardo enorme. De fato, ela é geralmente um fardo insuportável. E se a condução das tarefas não for coordenada, a organização tende a tornar-se bastante ineficiente.

\subsection{A falácia de Taylor: não há necessariamente uma maneira melhor, universal}

Numa era onde a resposta a cada questão científica tem uma resposta única, universalmente correta (e um bilhão de outras erradas), a idéia de que cada questão gerencial deve ter uma resposta única, universalmente correta, parece não só atraente, mas também plausível. Mas a gerência parece-se menos com a ciência do que com a engenharia. $\mathrm{E}$ as questões de engenharia têm várias respostas possíveis (Behn, 1996: 100-2). Em algumas circunstâncias, algumas respostas serão melhores do que outras. Mas mesmo para um simples conjunto de circunstâncias, podem existir múltiplas respostas corretas.

\subsection{A falácia de Wilson: a implementação é inerentemente política}

Finalmente, é impossível separar a administração da política e do Estado. Administração não é só uma questão de eficiência e regras racionais; mas envolve inerentemente escolhas políticas, ou ao menos dependentes de como comportam as autoridade eleitas nos Estados Unidos. Elas não podem - coletiva ou individualmente pensar em todas as circunstâncias possíveis, situações e instâncias que irão surgir. Não importa o quanto tentem os líderes políticos do executivo e legislativo, eles não poderão desenvolver um conjunto de políticas que serão aplicáveis a todas as situações. Os casos individuais não serão atendidos por nenhuma política - nem por várias políticas contraditórias. Portanto, os encarregados da mera implementação eficiente das políticas oficiais autorizadas devem — por definição tomar decisões políticas também.

$\mathrm{Na}$ verdade, Wilson reconheceu que os assuntos administrativos eram conectados aos políticos — ou ao menos que a divisão da responsabilidade entre as políticas e a administração é uma questão inerente da política.

O estudo da administração, revisto filosoficamente, está fortemente conectado com o estudo da distribuição adequada da autoridade constitucional. Para ser eficiente, a administração enquanto ciência deve descobrir os arranjos mais simples pelos quais a responsabilidade pode ser corretamente atribuída aos dirigentes; qual a melhor forma de dividir autoridade sem dificultá-la, e responsabilidade sem obscurecê-la. 
No entanto, Wilson esperava que "o estudo administrativo possa descobrir os melhores princípios sobre os quais basear tal distribuição" de poder entre os dirigentes encarregados da política e da administração (1887: 19-20).

Mas suponhamos que tal estudo administrativo descubra alguns excelentes (se não necessariamente os melhores) princípios para dividir o poder entre dirigentes políticos e administrativos. O que aconteceria então? Tais princípios seriam rapidamente codificados como leis? Todos duvidamos. Pois a distribuição da autoridade constitucional — particularmente entre os poderes legislativo e executivo - é (nos Estados Unidos) uma fonte de contínua competição política. Tal distribuição de autoridade - e portanto de poder - pode ser influenciada pelas conclusões do estudo, mas é determinada pela negociação política, e portanto pelo poder político.

No entanto, no final do século XX, como tentamos desenvolver novas estratégias para melhorar o desempenho inadequado dos governos, o paradigma da administração pública continua extremamente atraente. Por que? Porque ele é abençoado pela simples e irresistível teoria da accountability política, que o novo paradigma da gestão pública ainda tem de incorporar.

John Maynard Keynes escreveu que "Homens práticos, que acreditam serem isentos de quaisquer influências particulares, são geralmente os escravos de algum economista já falecido" (1964: 383). Nenhum deles, Wilson, Taylor ou Weber, era economista. Todos faleceram há mais de 70 anos. No entanto, pessoas que sabem a respeito do trio pouco mais do que o fato de Wilson ter sido presidente dos Estados Unidos durante a $1^{\text {a }}$. Guerra Mundial são, sem dúvida, escravas de suas idéias.

\section{A questão da accountability democrática}

$\mathrm{O}$ que queremos dizer com accountability democrática? O que significa, quando dizemos que, da perspectiva do paradigma da administração pública, tanto a política quanto a administração devem ter accountability? Accountability perante quem? Para que? De que forma? Como exatamente poderemos exigir accountability do governo? De fato, empregamos a frase "cobrar accountability do governo" como se seu significado fosse óbvio ${ }^{11}$. Porém, como iremos cobrar accountability de quem e por quê?

Os defensores do paradigma da gestão pública respondem: não esperem que respondamos pelo processo; mas sim pelos resultados. A afirmação, ao menos, soa como uma resposta à parte do por quê da pergunta. Na verdade, porém, ela só faz apresentar outra questão: quem decide por quais resultados produzidos o governo deveria responder? 
Assim, a questão da accountability torna-se (ao menos da perspectiva do paradigma da gestão pública): como iremos cobrar accountability de quem e para produzir quais resultados?

Finalmente, existe um ponto adicional envolvido na questão da accountability. Quem somos 'nós'? Quer dizer, quem, exatamente, irá assumir as atividades de cobrança de accountability? Será esse papel dos cidadãos em geral, tanto pelo processo eleitoral quanto por outro modo qualquer? Será esse papel dos representantes eleitos pelos cidadãos especialmente os parlamentares eleitos - pelo tradicional processo de audiências de controle? Deverão existir vigilantes oficialmente autorizados, tais como auditores e inspetores-gerais, ou vigilantes não-oficiais, auto-escolhidos, como os grupos de cidadãos e jornalistas? Para criar uma nova teoria de accountability democrática, os defensores do novo paradigma da administração pública precisam responder à seguinte questão essencial primordial:

Como e quem irá cobrar accountability de quem para produzir quais resultados?

Portanto, a questão da accountability democrática tem quatro componentes, levantando quatro perguntas, suplementares mas interrelacionadas:

- quem decidirá quais resultados devem ser produzidos?

- quem deve responder pela produção desses resultados?

- quem é responsável pela implementação do processo de accountability?

- como irá funcionar esse processo de accountability?

O novo paradigma da gestão pública precisa de um paradigma correlato de accountability que responda essas quatro perguntas.

\subsection{Quem decidirá quais resultados devem ser produzidos?}

Esta é a mais problemática questão levantada pelo paradigma da nova gestão pública. Pois a nova gestão pública pressupõe que às vezes talvez freqüentemente - essas decisões serão tomadas pelos servidores públicos. Mas então, como fazem esses servidores, que não foram eleitos (mas são geralmente irremovíveis) para obter a autoridade necessária para tomar tais decisões políticas? Isso não seria responsabilidade exclusiva das autoridades eleitas (e de seus indicados políticos diretos)? Como podem os defensores da nova gestão pública ignorar aquilo que foi, por mais de um século, um dos princípios operacionais básicos da democracia americana?

A resposta oferecida pelos defensores da nova gestão pública é de ordem prática, e não teórica. Eles simplesmente afirmam que, apesar de ser verdade que segundo as regras do paradigma da administração pública tradicional os servidores públicos não devem tomar decisões políticas, eles freqüentemente tomam. Esse é, claro, o segredinho sujo da administração 
pública: os servidores públicos, de fato, fazem política. É típico que eles neguem que façam uma tal coisa, e insistam em que estejam simplesmente completando os detalhes administrativos das políticas gerais estabelecidas pelo processo político. Por mais de cem anos, estivemos mantendo a ficção de que os servidores públicos não fazem política.

Esta é uma ficção bastante conveniente (apesar de precária). Pois uma vez que confessemos a desagradável realidade de que, para que façam o seu trabalho, os servidores precisam tomar decisões políticas, nós deveremos negar o paradigma da administração pública. No entanto, se continuamos a professar publicamente tanto o princípio quanto a praticidade da dicotomia política-administração, os defensores da administração pública tradicional podem oferecer uma teoria internamente consistente para a implementação da política pública.

Aqueles que propõem uma nova gestão pública, porém, renderamse a essa vantagem, e aceitam que os servidores públicos tomem decisões políticas. De fato, eles defendem que os servidores públicos tomem decisões políticas. E assim ficam sem saída. Eles precisam de uma nova teoria política que explique por que e como isso será (ou poderá ser) consistente com a accountability democrática. Necessitam de uma teoria que responda a quatro questões inter-relacionadas, a respeito de como servidores públicos com maior autonomia e capacidade de resposta podem tomar decisões inovadoras em um governo democrático:

- A questão da tomada de decisão descentralizada: que teoria de governo democrático encoraja a tomada de decisão descentralizada enquanto mantém a accountability perante todo o Estado?

- A questão da responsividade: que teoria do governo democrático permite que indivíduos empregados públicos sejam responsivos às necessidades dos indivíduos cidadãos e ainda garanta que o governo trate todos com justiça?

- A questão do empowerment: que teoria do governo democrático permite aos servidores públicos exercerem poder discricionário e ao mesmo tempo garanta que continuemos sendo um governo regido por leis?

- A questão da inovação: que teoria do governo democrático permite — ou de fato encoraja - que trabalhadores na linha de frente sejam inovadores na busca de um melhor desempenho?

$\mathrm{O}$ problema da performance somente não chega a exigir uma nova teoria de accountability democrática; o enfoque na produção de resultados também não. Mas dar aos servidores públicos a autoridade de tomar decisões sobre quais resultados devem ser produzidos - e como exatamente devem ser produzidos — obriga os defensores do paradigma da nova gestão pública a pensar seriamente sobre a relação entre a eficácia de suas estratégias de gestão e a necessidade de accountability democrática. 


\subsection{Quem deve responder pela produção desses resultados?}

A resposta a essa pergunta deverá parecer óbvia: a agência responsável. Mas a nova gestão pública refere-se a servidores mais que capacitados, engajados em uma tomada de decisão inovadora, responsiva. A nova gestão pública não só rejeita a idéia de que servidores públicos sejam implementadores passivos (se considerados científicos) de decisões políticas; ela também rejeita o ideal burocrático de organizações separadas responsáveis pela implementação de políticas separadas.

Por detrás do conceito tradicional de administração pública e de accountability está a suposição implícita de que uma organização é responsável por uma política — ou ao menos de que toda política é responsabilidade de uma organização. Essa é a outra beleza da burocracia hierárquica. Cada componente da organização é claramente responsável pela implementação de uma política — ou de um componente dessa política. Para cada componente de uma organização, há um indivíduo claramente encarregado; portanto, cada indivíduo deve sempre ter accountability:

- O secretário de estado é responsável pela implementação da política educacional no estado.

- O secretário distrital municipal é responsável pela implementação da política educacional nas escolas do distrito ou municipais.

- O diretor da escola é responsável pela implementação da política educacional na escola.

- O professor é responsável pela implementação de política educacional na sala de aula.

O emprego da burocracia hierárquica na implementação da política torna a accountability individual bastante clara.

Esse arranjo ideal é, obviamente, outra ficção. Pois à medida que os propósitos que buscamos no governo tornam-se mais complexos, e portanto as políticas que buscamos implementar tornam-se também mais complexas, o mesmo ocorre com os arranjos organizacionais necessários para implementá-las. Novamente, porém, os defensores do paradigma da administração pública tradicional têm a solução mais fácil. Pois eles podem continuar insistindo em utilizar políticas antiquadas, ultrapassadas. Talvez devêssemos rotular este outro princípio da administração pública: a separação das políticas. Cada parte da legislação cria uma política que é implementada por uma organização. Chamemos a isso "princípio da lei única, política única, organização única".

Se esse princípio pelo menos uma vez descreveu a realidade, ele seguramente não o faz mais. Devemos reconhecer que os propósitos da maioria das políticas exigem a cooperação de várias agências. Eles devem 
exigir a cooperação de agências de vários níveis de governo - por exemplo, de agências ambientais das esferas federal, estadual e municipal. Exigirão também a cooperação de várias agências do mesmo nível por exemplo, de agências estaduais de proteção ambiental, agricultura, recursos hídricos e comércio. E, obviamente, a política muitas vezes exigirá também a cooperação de organizações privadas e sem interesse lucrativo. Os propósitos políticos ambiciosos que buscamos alcançar atualmente exigem o esforço cooperativo de uma rede de organizações ${ }^{12}$.

No entanto, como uma rede poderá responder pela produção de quais resultados? Como o conceito de accountability poderá aplicar-se a uma rede? Como se define uma rede? Quem faz parte de uma rede, e quem não faz? Quem na rede tem accountability? Na burocracia tradicional, essa questão é pouco ambígua. O gerente de cada nível tem accountability individual. Mas, numa rede cooperativa de indivíduos de fato, uma rede cooperativa de burocracias — não é fácil identificar o indivíduo, ou mesmo os indivíduos. E por que deveriam tais indivíduos responder? São eles coletivamente responsáveis pela produção do resultado global? Ou cada componente da rede é responsável somente pela produção do seu componente próprio, específico, daquele resultado? No mundo pós-burocrático (mesmo que tal mundo consista de redes de burocracia), não é fácil identificar quem tem accountability e por quê. Nesse mundo pós-burocrático, a questão da accountability torna-se ainda mais complicada:

Quem vai cobrar accountability de quem na rede pela produção de quais resultados? ${ }^{13}$

\subsection{Quem é responsável pela implementação do processo de accountability?}

Segundo o paradigma tradicional da administração pública, a resposta a essa questão é linear. Tanto as autoridades eleitas quanto o eleitorado têm a responsabilidade. As autoridades eleitas devem controlar a implementação da política pelas agências públicas. E o eleitorado está encarregado de controlar as autoridades. A linha de accountability parte dos servidores públicos, passa por aqueles indicados politicamente pelas autoridades e chega ao eleitorado.

É claro que, novamente, a realidade é um pouco distinta. Quase toda política pública é complicada, portanto a implementação da política e o controle de sua implementação também o são. Assim, tanto as autoridades eleitas quanto o eleitorado são incapazes de devotar muito tempo ao controle ${ }^{14}$. Essa é outra razão pela qual os servidores acabam tomando decisões políticas: é vaga a orientação política inicial, como também é vaga a orientação contínua de controle. 
Obviamente, algumas pessoas preocupam-se muito com a política e sua implementação. Mas tais stakeholders não buscam exercitar sua influência somente pelo voto. Ao contrário, eles criam seu próprio processo de accountability, independente do processo oficial. Buscam assim influenciar diretamente as escolhas de implementação feitas pelos servidores públicos e por aqueles indicados politicamente, oferecendo informação e aconselhamento, e fornecendo apoio organizacional e financeiro durante as eleições. Em geral, os stakeholders têm um profundo interesse pessoal; o processo formal de accountability, embora direto de maneira superficial, dilui qualquer influência individual; as autoridades eleitas não estão inerentemente interessadas ou ativamente engajadas na supervisão/controle; os servidores públicos tomam decisões políticas frequientemente com muito pouca orientação oficial; tais decisões são suscetíveis a influências - diante de tudo isto, stakeholders organizados são usualmente os mais ativamente envolvidos na criação de accountability, embora o processo por eles desenvolvido seja complemente estranho ao mecanismo da accountability concebido pelos fundadores do paradigma da administração pública.

Os defensores de qualquer paradigma da nova gestão pública poderiam simplesmente abraçar essa realidade. Poderiam rejeitar, como sendo utópico, o conceito tradicional de autoridades eleitas e cidadãos responsáveis pela implementação da accountability democrática e aceitar que os stakeholders de qualquer política são as únicas pessoas com interesse suficiente para dedicar tempo às questões de accountability. ${ }^{15}$ Porém o resultado parece ser ligeiramente inconsistente. Por que deveria ser delegada (mesmo que extra-oficialmente) aos mais organizados - mesmo que eles tenham o maior interesse direto na política — a responsabilidade de implementar a accountability? O que terá acontecido com a accountability perante o Estado? ${ }^{16}$

\subsection{Como irá funcionar esse processo de accountability?}

Segundo o paradigma da administração pública tradicional, o processo de accountability funciona de forma bastante linear. As autoridades eleitas são responsáveis pelo controle da implementação de cada política estabelecida por elas. Então, se os cidadãos não estão felizes com a política, com a implementação daquela política, ou com o controle daquela implementação, eles substituem as autoridades no momento das eleições. O processo de accountability funciona tanto por meio das autoridades eleitas quanto do eleitorado.

Infelizmente, na prática isso também não funciona tão bem quanto na teoria. Afinal, as autoridades eleitas estabelecem várias políticas. Algumas dessas políticas são por vezes conflitantes, até contraditórias. Al- 
gumas vezes uma agência deve implementar políticas conflitantes - ou

é responsável por implementar a política sem os recursos adequados. Isso complica significativamente o processo de accountability: complica tanto a parte do processo que cabe às autoridades eleitas como complica o papel da base eleitoral.

Se as autoridades eleitas apóiam uma política particular e fornecem recursos adequados para a agência implementadora, o controle da política é relativamente linear. As autoridades precisam criar mecanismos simples para verificar se a agência responsável está aplicando os recursos de forma adequada, se está implementando a política de forma inteligente, e se a política está produzindo os efeitos desejados. Caso contrário, as autoridades precisam mudar os dirigentes da agência, o uso de recursos, ou a própria política.

Mas como poderão as autoridades controlar políticas com as quais elas discordem? Deverão controlar estritamente a implementação da política, verificando se a mesma está atingindo os propósitos desenhados por seus criadores? Ou deverão também reexaminar os propósitos originais? E se seu controle der origem a uma crítica, terá sido por causa de uma implementação inadequada, ou será inadequada a própria política? Qualquer resposta é confusa, pois é muito difícil (se não impossível) separar tais motivos.

E para que deveriam as autoridades ter accountability perante os cidadãos? Para cada política individual? Ou pelo conjunto das políticas que elas apóiam? Ou pela totalidade das políticas estabelecidas pelo governo? Ou pela política única que interessa mais a cada cidadão? ${ }^{17}$.Uma vez que uma vasta gama de políticas diversas esteja sendo implementada, que papel têm os cidadãos na accountability dessas políticas?

Numa democracia parlamentar, a linha de accountability é muito mais clara. O governo - o partido com a maioria parlamentar, e portanto encarregado do poder executivo - é responsável por todas as políticas. Os cidadãos podem gostar de algumas políticas, e de outras não, mas eles saberão quem são os responsáveis. E a oposição leal busca constantemente deixar claro as suas diferenças com essas políticas ${ }^{18}$. Os cidadãos ainda poderão escolher entre pacotes de políticas; uns poucos estarão totalmente satisfeitos com cada política, e com a implementação de cada política naquele pacote. No entanto, o papel do cidadão na implementação do processo de accountability durante as eleições periódicas é ainda mais linear.

Os Estados Unidos, porém, não contam com uma democracia parlamentar. Assim, os cidadãos americanos não podem fazer todo o processo de accountability funcionar facilmente. Quando eles votam, eles não podem enviar facilmente sinais efetivos sobre as políticas (ou a implementação) das quais eles discordam. 
Assim, nos Estados Unidos, o processo de accountability funcio-

na basicamente fora da estrutura constitucional. Isso é uma pena, pois existe pouco controle ou equilíbrio nesses mecanismos extra-constitucionais de accountability. Em algumas circunstâncias, stakeholders distintos podem controlar ou equilibrar cada lado. Mas se houver uma coalizão de vários stakeholders, se eles negociarem um acordo que reflita os maiores interesses de cada um deles, eles poderão criar um processo de accountability livre de controles ou equilíbrios de outras forças, que fracassará em incorporar os interesses do Estado.

Novamente, os defensores do paradigma da nova gestão pública poderiam simplesmente aceitar e sacramentar essa realidade. Mas isto ainda não tornaria o processo de accountability mais democrático.

\section{Poder discricionário, responsabilidade e confiança}

A contrário de Frederick Taylor e Max Weber, Woodrow Wilson acreditava no poder discricionário da administração. Sua ciência da administração não previa um autômato sem julgamento próprio seguindo a pauta elaborada pelos líderes políticos; ao contrário, sua "ciência eminentemente prática da administração" iria "descobrir, primeiro, o que o governo pode fazer de maneira correta e bem-sucedida, e segundo, como ele pode fazer essas coisas corretamente, e com o máximo possível de eficiência e o mínimo possível de custos, seja financeiro ou de energia”. Portanto, ele pregava, especificamente, a delegação ao aparato administrativo do governo do poder discricionário necessário para empregar, desenvolver e adaptar os meios mais eficientes e eficazes de implementação de políticas. Wilson afirmava que "o administrador deveria ter e tem vontade própria na escolha dos meios para executar seu trabalho. Ele não é e não deve ser um mero instrumento passivo"(1887: 11-9).

Além disso, dizia Wilson, sem essa delegação de poder discricionário, é impossível estabelecer responsabilidades: "autoridade e poder discricionário irrestritos parecem-me condições indispensáveis da responsabilidade". Assim, "para ser eficiente", o estudo da administração para Wilson deveria "descobrir os arranjos mais simples pelos quais a responsabilidade pode ser inequivocamente atribuída aos dirigentes; e a melhor forma de dividir autoridade sem dificultá-la, e responsabilidade sem obscurecê-la" (1887: 19-20).

A distinção entre política e administração existe de ambas as partes. A administração de Wilson não é só estritamente o ato de executar politicamente as leis aprovadas. Mas também a política não deve intrometer-se em tal execução: "Mesmo que a política estabeleça as tarefas da administração", afirmava Wilson, "ela não deve ser utilizada para 
manipular seus gabinetes" (1887: 18). Como outros reformadores que surgiram na história da nossa nação, Wilson queria tornar o governo mais parecido com o mundo dos negócios — mantendo assim a política fora da administração.

Nesse ensaio, Wilson alertou contra "o erro de se tentar fazer demais por meio do voto". Para explicar seu raciocínio, ele ofereceu uma metáfora:

“Autogovernar não significa ter uma mão em tudo, da mesma forma que cuidar de uma casa não consiste necessariamente em preparar o jantar com as próprias mãos. O cozinheiro deve receber muita autonomia para administrar o forno e o fogão" (1887: 20).

De fato, se você disser ao cozinheiro exatamente como administrar o forno e o fogão, então o cozinheiro já não será o responsável pela qualidade do jantar. Será você. ${ }^{19}$

Mas, como também notou Wilson, para delegar autonomia ao cozinheiro, o dono da casa deve confiar no cozinheiro; da mesma forma, para delegar autonomia a uma agência administrativa, o público deve confiar na agência. Obviamente, os donos de casa confiam em seus cozinheiros mais do que o público confia em suas agências administrativas. Como observou Wilson: "todos os soberanos suspeitam de seus servos, e o povo soberano não é uma exceção à regra" (1887: 20). ${ }^{20}$

Para Wilson, tal suspeita não é necessariamente má: "Se tal suspeita pudesse ser esclarecida com sábia vigilância, ela seria de todo saudável; se a tal vigilância pudesse ser adicionado uma dose inequívoca de responsabilidade, ela seria de todo benéfica". Mas por si mesma, continua Wilson, a suspeita "nunca é saudável, seja na mente pública ou privada". A suspeita deveria ser combinada com confiança: "Confiança é a força de todas as relações da vida". Assim, tanto na constituição das composições políticas quanto na criação de sistemas administrativos, é necessário dar-lhes o desenho para que abriguem confiança: "da mesma forma que o gabinete do reformador constitucional deve criar condições de confiabilidade, assim também o gabinete do administrador deve modelar a administração com condições de responsabilidade claras, para garantir que a confiança valha à pena" (1877: 20).

Ao contrário de Woodrow Wilson, porém, James Madison não acreditava em confiança. Assim, ele desenhou uma constituição que não criava condições de confiança. De fato, Madison desenhou uma constituição que reforça a suspeita. Ao desenhar múltiplas instituições com responsabilidade específica de equilibrar e controlar uma à outra, Madison criou instituições rivais que suspeitam - e não confiam - umas das outras. Como se isso já não fosse bastante, nós contínuamente criamos 
novas instituições - como os inspetores gerais e promotores independentes - com o único objetivo de suspeitar dos outros. E, claro, existem os jornalistas, que estão no ramo da suspeita em tempo integral. Como observou Wilson, "nós continuamos a criticar quando deveríamos estar criando" (1887: 16).

Nessa crítica da nova gestão pública, Donald Savoie comentou sobre o problema dos erros:

“A administração pública opera em um ambiente político que está sempre à busca de erros e que demonstra níveis extremamente baixos de tolerância com as falhas; no mundo dos negócios não importa muito que você se equivoque $10 \%$ do seu tempo, desde que você apresente lucro no final do ano. No governo não importa muito que você esteja certo $90 \%$ do seu tempo porque a atenção será dirigida aos 10\% de tempo em que você esteve errado" (1995 a: 114-5).

De fato, no governo, não importa muito se você está certo $99 \%$ do tempo, porque a atenção será voltada para aquele $1 \%$ de tempo em que você esteve errado. É por isso que os Dez Mandamentos do Governo são "Você não deve cometer erros. Você não deve cometer erros . . . Você não deve cometer erros" (Behn, 1991b: 1).

A suspeita institucionalizada mina a confiança. Uma instituição encarregada de suspeitar revelará, a menos que seja totalmente incompetente, comportamentos suspeitos. Pouco importa se a conduta dúbia tiver sido um erro insignificante, na tentativa de seguir regras para compra de suprimentos, ou um erro maior e mais grave, no julgamento de uma política. De fato, os pequenos erros de procedimento devem ter um efeito maior na destruição da confiança no governo do que os principais fracassos políticos. Isso porque a realidade do pequeno erro de procedimento é óbvia para todos, enquanto a existência de um grande fracasso político é sempre objeto de muita discussão ${ }^{21}$. Assim, a descoberta diária e repetida de pequenos faltas de atenção aos detalhes das regras burocráticas deve ter um impacto negativo maior na confiança no governo do que os debates políticos contínuos sobre temas maiores e mais substantivos.

A confiança é um bem frágil — principalmente no governo. Ainda assim, todo governo requer confiança. Wilson compreendeu isso. Ademais, a responsabilidade e o poder discricionário requeridos para a implementação do paradigma da nova gestão pública exigem um aumento significativo da confiança dos americanos nos seus vários governos. Infelizmente, temos poucas instituições públicas dedicadas à tarefa da construção da confiança. Ao contrário, dispomos de numerosas organizações, dentro e fora do governo, encarregadas de identificar, perseguir e expor nossas suspeitas — minando assim a confiança. Para mudar nossa 
opinião sobre como deveremos conduzir os assuntos de governo - para substituir o paradigma tradicional da administração pública pelo da nova gestão pública — os defensores do novo paradigma deverão inventar formas de reforçar a confiança pública.

\subsection{A confiança e o paradoxo de Moore}

Como se não bastassem a falta de confiança inerente e a criação institucionalizada da suspeita, o estilo dos novos gestores públicos pode ameaçar ainda mais a confiança pública. Gestores públicos eficazes devem não só tomar iniciativa. Para realmente produzir resultados nas grandes e burocráticas agências públicas de hoje, os gestores públicos muitas vezes necessitam de níveis especialmente altos de dedicação, energia e audácia. De fato, o protótipo do novo gestor público não é puramente empresarial; ele é geralmente impetuoso e agressivo — aproveitando as oportunidades mais evidentes, aceitando publicamente a responsabilidade pelos sucessos e fracassos, e debochando não só dos difamadores, mas também daqueles mais criteriosos.

"Gestão pública é diferente de administração pública", enfatiza Donald Savoie, um dos críticos da nova gestão pública. Ademais, gestores públicos são diferentes dos administradores públicos. Savoie apresenta o contraste nos estilos de operação: "ao contrário da linguagem da administração pública tradicional que evoca imagens de regras, regulamentos e processos letárgicos de tomada de decisão, a própria palavra gestão implica em decisão, uma mente dinâmica e uma tendência à ação" (1995a: 113). No entanto, os cidadãos não estão bem certos de confiarem nesses empresários governamentais.

O resultado é o que Mark Moore descreve como um "paradoxo interessante": por um lado, como liderança pessoal e responsabilidade parecem ser a chave de inovações bem-sucedidas, elas devem ser valorizadas; por outro, a arrogância e o estilo mais vistoso que sempre acompanham a liderança pessoal normalmente atraem hostilidade e suspeita no setor público.

Um inovador bem-sucedido tanto no ramo empresarial quanto governamental, observa Moore, precisa de "uma vontade executiva de tomar a iniciativa e aceitar a responsabilidade, mantendo-se ao mesmo tempo modesto com respeito às próprias contribuições e generoso ao dar crédito aos outros". Mesmo assim, continua ele, "os executivos do setor público devem errar mais do lado da modéstia" para não "provocar a vigilância cerrada da imprensa nem antipatia”. Isso cria o paradoxo de Moore: "o público espera um estilo de gestão no setor público que seria ineficaz, caso os gestores estivessem realmente envolvidos nele" (1993: 133-4). 
Gestores públicos que exercitam pouca iniciativa produzem poucos resultados e assim ameaçam a confiança pública no governo. Gestores públicos que são líderes podem produzir resultados, mas pelo seu estilo arruinam a confiança pública. Pois afinal, eles funcionam dentro de organizações que possuem regras detalhadas sobre como fazer - e não fazer — tudo. No entanto, observa Marc Zegans, "as organizações obcecadas por regras transformam os tímidos em covardes e os ousados em fora-da-lei' (1997, 115).

Talvez exista algum nível intermediário mais feliz: a liderança que produz resultados sem ser tão agressiva. Mas com todas as outras considerações e interesses que o gestor público moderno deve equilibrar, chegar a esse ponto ideal parece um fardo desalentador.

\section{Adaptando o mecanismo existente de accountability retrospectiva}

Administradores públicos são responsáveis por processos. E o método tradicional de accountability pelos processo de trabalho é relativamente linear: o Poder Legislativo estabelece regras gerais para serem seguidas em vários processos, e unidades reguladoras em várias agências do executivo codificam-nas com regulações mais detalhadas. A seguir, a agência passa a manter alguns registros, para demonstrar que segue tais processos fiel e consistentemente, podendo eventualmente emitir um relatório resumido de tais registros. Ao mesmo tempo, auditores examinam tais registros detalhadamente, verificando se todos os processos foram realmente seguidos (e detectando qualquer comportamento desonesto). Outros - jornalistas, organizações de vigilância e stakeholders - também escrutinam a agência com bastante cuidado, identificando as instâncias onde a agência falhou ao implementar seus próprios processos. E quando um padrão de erros emerge, ou um caso particularmente notório é identificado, ou um erro pequeno mas atraente é descoberto, comitês legislativos realizam audiências e adotam ações corretivas. Às vezes, as pessoas que falharam em seguir os processos prescritos são despedidas, ou sofrem medidas disciplinares. Além do mais, como tudo isso é bastante divulgado, as agências são incentivadas a atingir o cumprimento dos processos estabelecidos.

Gestores públicos são responsáveis por resultados. Por que então o processo tradicional de accountability não pode ser aplicado a resultados, ao invés de processos? Por que não podemos simplesmente adaptar os mecanismos tradicionais de accountability ao nosso novo enfoque no desempenho? Por exemplo: o Poder Legislivo estabeleceria as regras gerais para os resultados que devem ser atingidos durante o ano fiscal 
seguinte, e uma organização do poder executivo as codificaria em metas

mais detalhadas. A seguir, a agência manteria registros para demonstrar que está fazendo progressos com respeito ao cumprimento das metas, e esporadicamente emitiria um relatório resumindo suas conquistas. Enquanto isso, auditores examinariam tais registros detalhadamente, verificando se as metas teriam sido realmente atingidas (e detectando qualquer comportamento desonesto). Outros — jornalistas, organizações de vigilância e stakeholders - escrutinariam a agência cuidadosamente, identificando as instâncias onde a agência falhou no cumprimento de suas próprias metas. E quando um padrão de falhas fosse identificado, ou uma falha particularmente significativa ou um erro pequeno mas atraente fosse descoberto, comitês legislativos realizariam audiências e adotariam ações corretivas. As pessoas que falhassem em atingir suas metas seriam despedidas, ou sofreriam medidas disciplinares. Além do mais, como tudo isso seria bastante divulgado, as agências seriam incentivadas a atingir suas metas.

Isso é simplesmente o mecanismo tradicional de accountability retrospectiva, empregado atualmente pelas legislaturas para garantir que as agências sigam todos os processos desenhados para garantir justiça e eficiência. É genérico, exceto pelo fato de ter sido adaptado para criar um mecanismo de accountability assegura que às agências executoras o alcance de metas específicas.

Esse processo de accountability exige que a legislatura estabeleça ao menos propósitos gerais; mas as legislaturas já o fazem. Ele também exige que as agências executoras estabeleçam metas específicas que possam indicar o progresso rumo à concretização de tais propósitos; considerando todas as aspirações pessoais dos gestores públicos de serem todo-poderosos no governo, eles deveriam estar dispostos a estabelecer uma ou duas metas específicas. ${ }^{22}$ Então, uma vez que a agência tenha escolhido sua(s) meta(s) para o ano fiscal, o processo de accountability por resultados pode seguir o processo de accountability para processos, que já terá sido desenhado, empregado e aperfeiçoado.

Para implementar esse mecanismo de accountability retrospectiva, a legislatura terá de fazer duas coisas. Durante o ano fiscal, revisar a escolha da meta. Depois do ano fiscal, avaliar a capacidade da agência de atingir a meta.

\subsection{Revisando a meta}

Após a escolha da meta, o Poder Legislativo deve determinar se ela faz sentido. Ele pode estipular pessoal para analisar a meta, considerar alternativas e acompanhar o processo da agência encarregada de escolher a meta. Pode realizar audiências para determinar se os 
stakeholders e o público em geral estão satisfeitos com as metas. A seguir, caso o Poder Legislativo esteja insatisfeito com a escolha da agência, pode solicitar à agência que repense sua meta e mande de volta uma definição. Se estiver extremamente insatisfeito com a escolha da meta, pode ainda pressionar a agência a alterar sua meta, sancioná-la, tentar convencer o chefe do Executivo a alterar o quadro gerencial da agência, ou aprovar legislação modificando a meta para o ano fiscal atual.

\subsection{Avaliando o cumprimento da meta}

Quando o ano fiscal terminar, o Poder Legislativo precisa verifica se a meta foi ou não cumprida. Pode solicitar um relatório à agência, solicitar uma auditoria desse relatório, e nomear alguns funcionários para fornecer sua própria avaliação sobre quão bem saiu-se a agência. Pode realizar audiências para determinar se os stakeholders e o público em geral estão satisfeitos com o desempenho da agência. A seguir, caso o Legislativo esteja insatisfeito com o desempenho da agência, ele pode determinar as causas e solicitar que a agência desenvolva um plano para melhorar seu desempenho durante o ano fiscal seguinte. Se estiver extremamente insatisfeito com o desempenho, pode pressionar a agência a realizar alterações gerenciais específicas, sancioná-la, tentar convencer o chefe do Executivo a alterar o quadro gerencial da agência, ou aprovar legislação criando metas novas e distintas para o ano fiscal seguinte. Parece correto adaptar os mecanismos retrospectivos existentes da accountability por processos às novas necessidades de criação de um mecanismo retrospectivo para estabelecer a accountability por resultados.

Ademais, esse mecanismo genérico de accountability é mesmo similar ao modo como o mundo dos negócios cria accountability por resultados. Os gestores de várias divisões e de outras unidades chegam a um acordo com seus superiores a respeito das metas para o ano. Isso pode estar sujeito a mais negociações do que pode acontecer entre uma agência executiva e o Legislativo (mesmo que seja uma negociação claramente privada). Uma vez iniciado o ano fiscal, a gerência monitora o desempenho de cada divisão. E, ao final do ano, conduz uma auditoria, determina quais divisões atingiram suas metas e quais não, toma ações corretivas quando necessário, e negocia novas metas para o ano seguinte. Se uma divisão atingiu sua(s) meta(s) (sem fazer nada ilegal) ela foi um sucesso - foi responsável pela administração dos recursos do proprietário e por suas obrigações maiores para com a sociedade.

O mecanismo de accountability do setor privado consiste no acordo sobre metas específicas a serem alcançadas durante um período específico, no acompanhamento freqüente do progresso durante o período, e na avaliação retrospectiva ao final do mesmo. A única grande diferença en- 
tre os mecanismos público e privado seria o método de se decidir que

meta deve ser buscada por uma agência governamental ou uma divisão de uma empresa.

\section{Políticas de processos e políticas de resultados}

Por que a accountability por resultados não pode funcionar exatamente como a accountability por processos? Ou por que a accountability por resultados no governo não pode funcionar da mesma forma que a accountability por resultados do setor privado?

Porque processos são diferentes de resultados. E porque negócios privados são diferentes de governo. Especificamente, as políticas de processo são diferentes das políticas de resultados. Isso torna-se rapidamente óbvio no passo inicial do estabelecimento de metas específicas. Pois novamente há uma pergunta-chave: metas de quem? Quem decide quais resultados devem ser produzidos?

O Poder Legislativo poderia, é claro, fazê-lo. Afinal, ele estabelece processos. Algumas vezes, o Legislativo cria processos bastante detalhados. Outras vezes, formula somente processos gerais, deixando o Poder Executivo adicionar os detalhes mais específicos - o tempo todo reservando-se o direito de controlar, modificar ou cancelar tais detalhes. Por que então o Legislativo não o faz?

Porque o Legislativo não deseja fazê-lo. Ele, como corpo coletivo (e cada legislador individual também) não quer estabelecer metas específicas. Como enfatiza Donald Savoie, os objetivos do governo "são pouco claros porque os políticos assim o preferem" (1995b: 135). Esclarecer os objetivos é gerencialmente correto, mas politicamente irracional. Pois ao esclarecer os objetivos, os políticos devem optar entre bases eleitorais adversárias e valores conflitantes. Pela experiência, as autoridades eleitas aprenderam que podem ganhar mais reconhecimento, apoio e votos sendo confusas a respeito dos resultados que irão produzir do que sendo claras a esse respeito. Um governador uma vez disse aos seus auxiliares: "nunca ponham um número e uma data na mesma frase".

Qualquer discussão sobre objetivo específico para um programa específico ou uma agência específica para um determinado ano introduz novamente os desacordos políticos, que haviam sido cuidadosamente minimizados pela incorporação de propósitos vagos (ao invés de precisos) na legislação. Um preâmbulo legislativo que especifique propósitos gerais, múltiplos e talvez até contraditórios pode fazer muitas pessoas felizes. Os propósitos estabelecidos na legislação são múltiplos e gerais, não porque nenhum legislador não tenha uma idéia clara de que meta 
gostaria de atingir; ao contrário, o preâmbulo contém propósitos múltiplos gerais porque, embora vários legisladores possam identificar um ou mais objetivos específicos a serem atingidos, eles não conseguem concordar sobre objetivos comuns.

O senador William Roth era a força principal do Goverment Performance and Results Act (GPRA), concebido para ter todas agências federais especificando os resultados a serem produzidos. Roth queria que o Congresso estabelecesse metas específicas para agências específicas. "Sob a legislação," Roth escreveu:

"seria exigido que as agências federais desenvolvessem metas mensuráveis para seus programas. Eu acredito que nós podemos dar um passo além, e também exigir que o próprio Congresso exercesse um papel direto no estabelecimento de ao menos algumas dessas metas. O Congresso cria e financia os programas, então ele deveria dar alguma indicação de como ele espera que eles sejam cumpridos... O Congresso tem a obrigação de dizer aos contribuintes americanos que resultados pretendemos alcançar com o dinheiro que gastamos, e essa exigência deveria ser incluída na legislação” (Senado americano, 1993: 57-9).

Isso soa razoavelmente suficiente. Mas senadores e deputados apressaram-se em não aceitar o convite de Roth. Seus debates sobre propósitos vagos já são acalorados o bastante; eles não desejariam criar debates ainda mais impertinentes sobre metas específicas.

Ainda assim, sugere o GPRA, pode ser possível criar accountability por resultados sem que o Congresso especifique inicialmente que resultados quer alcançar. A solução pode ser fazer com que as agências os especifiquem. É claro que isso transfere do Legislativo para o Executivo a carga incômoda de escolher entre propósitos e valores opostos. Mas, pelo menos, um corpo legislativo - o Congresso americano - tem demonstrado sua determinação em fazer precisamente isso. Talvez outros poderes legislativos, pressionados em produzir resultados, mas ainda pouco dispostos a especificar quais resultados, achará que isso é aceitável de qualquer modo. O Legislativo rende-se a certa influência e controle; mas evita alguns desacordos bastante desagradáveis.

Mas será que isso cria accountability? Isso irá assegurar accountability por resultados? Afinal, as agências executivas podem relutar tanto quanto o Legislativo em criar desacordos desagradáveis e os ataques inevitáveis que surgem no momento da escolha das metas. Da mesma forma, elas também podem trapacear. O Legislativo pode criar um processo, um formulário e uma data limite, exigindo que cada agência especifique um ou vários objetivos. Mas ele não pode forçar as agências 
a levar tal requerimento a sério, ou a cumprir a tarefa com inteligência.

As agências sempre poderão optar por metas não-controversas e sem conseqüências. Elas também podem sempre escolher metas facilmente atingíveis. Dados todos os obstáculos que o Legislativo tem forçado o Executivo a saltar, por todos esses anos, as agências desenvolveram uma vasta experiência em corridas de obstáculos. Elas podem facilmente descobrir como saltar mais este.

Será que o Poder Executivo evita a intenção do Legislativo quando cria as regras e regulamentos que estabelecem a estrutura do processo de accountability? Não necessariamente. Para cada regulamento há uma razão; cada regulamento é formulado para prevenir a recorrência de um erro prévio. Não existe limite para o número de regulamentações que o Legislativo ou o Executivo podem criar. Além disso, politicamente falando, a existência de mais regulamentações é sempre melhor. A existência de mais regulamentações significa que a agência está garantindo maior justiça, mais eficiência. Significa que a agência está fazendo um bom trabalho, criando processos justos e eficientes. E mais, o Legislativo não resiste a uma maior regulação. Ele próprio busca mais; ele cria outras para si, e pressiona o Executivo a fazê-lo também. Essa não é, porém, uma pressão por mais regulamentação no geral, mas sim uma pressão por um maior número de regulamentações menores, individuais, todas contribuindo para mais — bem mais.

Poderia a mesma coisa ocorrer com as metas? Talvez. Uma agência do executivo encarregada de criar metas, que não queira ofender nenhum stakeholder ou negligenciar qualquer valor, pode simplesmente seguir o exemplo do Legislativo: ela também pode criar metas múltiplas e vagas. Nesse caso, o Legislativo deve criar suas próprias metas específicas, ou aceitar as metas vagas do Executivo. Caso o Legislativo seja muito insistente, ele pode exigir que a agência escolha somente uma meta. Nesse caso, a agência pode fazer exatamente o que foi pedido - escolher somente uma meta, criando precisamente o tipo de luta que o Legislativo vinha tentando evitar.

Processos e resultados têm atributos políticos bastante diferentes. As controvérsias acerca dos processos são diferentes das controvérsias sobre resultados. Assim as políticas de processos são diferentes das políticas de resultados. Conseqüentemente, não deve ser fácil fazer pequenas alterações nos mecanismos específicos existentes, utilizados para processos, e fazê-los funcionar bem para resultados.

\subsection{Destacando responsabilidades}

"Os dois inimigos da accountability são os objetivos pouco claros e o anonimato", escreveu Sanford Borins. Ele afirma ainda, na sua defesa 
do paradigma da nova gestão pública, que "ao promover a especificidade das metas e reduzir o anonimato, a nova gestão pública está fortalecendo a accountability" (1995a:125-6). A importância de se estabelecer e perseguir metas específicas é clara. De fato, os vários defensores do paradigma da nova gestão pública podem ter distintos paradigmas em mente, mas todos compartilham o mesmo enfoque nas metas: o trabalho do gestor público é atingir metas específicas. Mas como pode exatamente a nova gestão pública eliminar o anonimato?

Woodrow Wilson entendeu bem a necessidade de eliminar o anonimato burocrático:

"A atenção pública deve ser facilmente direcionada, em caso de boa ou má administração, somente ao homem que mereça reconhecimento ou culpa. Não há perigo no poder, desde que ele não seja irresponsável. Se ele for dividido, repartido em muitas frações, ele será obscurecido; e se for obscurecido, terá tornadose irresponsável. Mas se ele for concentrado nas chefias de serviço e nas chefias de áreas e setores, será facilmente controlado e registrado" (1887: 20).

No entanto, apesar de toda a influência de Wilson, ele não convenceu as pessoas a criarem um sistema de agências de governo que destacasse a responsabilidade dos chefes de cada agência e seus poderes. Por que?

Porque, eu acho, as organizações que separam expressamente a política da administração, obscurecem de modo inerente (se não conscientemente) toda a responsabilidade, exceto a do nível mais alto. Os políticos são responsáveis pela política e por tudo o que flui dela. $\mathrm{O}$ único trabalho dos servidores públicos é executar cientificamente essa política. Como eles podem ser responsáveis? (Ao mesmo tempo, como pode a pessoa na chefia de qualquer agência ser realmente responsável pelo comportamento dos indivíduos protegidos pelo serviço público que trabalham vários níveis abaixo na hierarquia da agência?).

De fato, as burocracias são - quase por definição — anônimas. Neutralidade burocrática é quase o mesmo que anonimato burocrático. Quando visitamos uma burocracia governamental e irritamo-nos com um burocrata por aplicar-nos (de forma neutra) alguma regra estúpida, sabemos (de maneira analítica, se não emocional) que não podemos realmente culpar o burocrata. Nosso tratamento - não importa quão absurdo - não é uma conseqüência da personalidade do burocrata. É o sistema de regras - e de punição pela violação dessas regras — que motiva o burocrata a comportar-se de forma burocrática. Porque deveria ele tomar para si a responsabilidade por um sistema concebido por alguém 
acima dele na hierarquia, sem mesmo pedir aos trabalhadores da linha de frente suas sugestões? Ao mesmo tempo, como pode o chefe da agência ser realmente responsável pela aplicação das regras por parte dos indivíduos protegidos pelo serviço público e que trabalham vários níveis abaixo dele na hierarquia da agência - especialmente se as regras foram impostas pelo Legislativo ou por outra unidade reguladora externa?

Um sistema de metas específicas a serem atingidas durante o ano fiscal corrente pode ressaltar um pouco mais de responsabilidade. Se a meta é estabelecida pelo Legislativo ou pela própria agência, o diretor da agência é o responsável pela sua consecução. Mas o resto da organização ainda está na berlinda. Por que aqueles que estão nos níveis mais baixos da hierarquia são responsáveis? Eles são simplesmente responsáveis por implementar o plano do diretor para a consecução daquela meta? Em caso positivo, suas vidas pouco mudaram. Eles continuam anônimos e, portanto, seguem não sendo responsáveis. Novamente, como pode o chefe da agência ser responsável pela implementação do plano por parte de indivíduos protegidos pelo serviço público que trabalham vários níveis hierárquicos abaixo dele?

Ainda assim, se metas específicas podem ajudar a eliminar o problema do anonimato nos níveis superiores de uma agência, porque elas não poderiam fazer o mesmo nos níveis mais baixos da hierarquia? Afinal, todos são gerentes intermediários. Todo gerente de toda unidade tem superiores e subordinados. Então por que não criar metas específicas para cada nível da organização? Tais metas subordinadas estariam diretamente ligadas à meta global da organização. ${ }^{23}$ De fato, se tais metas subordinadas fossem escolhidas de modo inteligente, a organização estaria simplesmente, ao cumprir todas as metas subordinadas, cumprindo sua meta global.

Tais metas de nível mais baixo não necessitam ser reportadas ao Legislativo. Elas poderiam ser, mas o Legislativo nunca seria capaz de examinar muitas delas com seriedade. Mas ao estabelecer simplesmente tais metas subordinadas - e talvez anunciá-las em toda parte — uma organização criaria responsabilidade nos níveis mais baixos, eliminando assim o anonimato, ao menos no seu interior. Além disso, se alguma coisa der errado, se a agência fracassar em atingir suas metas para o ano fiscal, a hierarquia das metas permitiria que a agência (ou o Legislativo) identificasse a causa do fracasso. Se algumas sub-unidades fracassaram em atingir suas metas individuais, elas e as seus superiores terão sido responsáveis. Se todas as sub-unidades atingiram suas metas, então o diretor da agência terá sido o responsável ao fracassar na criação de um sistema de metas subordinadas que, se atingidas, produziriam a meta global da agência. 
Especificar as metas ajuda a eliminar o anonimato. Exigir que uma agência pública tenha uma meta específica a cumprir até o ano fiscal destaca sua responsabilidade. Da mesma forma, exigir que os níveis mais baixos na hierarquia da agência tenham também suas metas específicas a serem cumpridas até o final do ano fiscal destaca também sua responsabilidade. ${ }^{24}$

\subsection{Ganhando a confiança pública}

“A administração nos Estados Unidos deve ser inteiramente sensível à opinião pública', afirma Wilson (1887: 21). Se, como Finley Peter Dunn, um contemporâneo de Wilson, observou, "a Suprema Corte seguir o retorno da ilicitude, certamente os servidores públicos o farão também".

Mas quão sensível à opinião pública a administração deve ser? Wilson chama isso de "o problema fundamental de todo o estudo" da administração: "que papel deve ter a opinião pública na condução da administração?" Wilson respondia que o público devia estar engajado, mas não demais:

"O problema é tornar a opinião pública eficiente sem o incômodo de tê-la intrometendo-se. Exercido diretamente, no controle de detalhes diários e na escolha dos meios diários de governo, a crítica pública é logicamente um incômodo desconfortável, um rústico lidando com máquinas delicadas. Mas como controladora das forças maiores de política formativa, tanto na política quanto na administração, a crítica pública de todo é segura e benéfica, indispensável. Deixemos o estudo administrativo encontrar a melhor forma de dar à crítica pública esse controle e de mantê-la fora de qualquer interferência...

O ideal para nós é um serviço público culto e auto-suficiente de tal forma que aja com bom senso e vigor, mantendo-se tão intimamente conectado com o pensamento popular, por meio de eleições e consulta pública constantes, como para encontrar arbitrariedades ou espírito classista totalmente fora de questão...

... estudos comparativos dos modos e meios do governo deveriam tornar-nos capazes de oferecer sugestões que irão praticamente combinar a abertura e o vigor da administração de tais governos com a docilidade pronta de todas as críticas públicas sérias e bemsustentadas" (1887: 20-4).

E, conforme os escritos de Wilson tornam claro, atingir o equilíbrio correto é difícil. Ademais, é ainda mais difícil criar um mecanismo formal de accountability que sempre atinja o equilíbrio correto. 
Para a nova gestão pública, o público tem interesse tanto na escolha das metas quanto na consecução delas. Portanto, qualquer mecanismo de accountability deve permitir que o público participe do debate sobre a escolha das metas, e no acompanhamento e avaliação da consecução das mesmas.

Mas como? Serão os mecanismos de eleição existentes adequados? Estarão as organizações dos stakeholders engajadas em demasia? Continuarão os jornalistas a focalizar sua atenção no processo — principalmente nos erros menores do cumprimento das regras e procedimentos? E o público irá comprometer-se com as metas que seu município estabeleceu para o sistema escolar, as metas de seu estado para as agências de apoio a famílias, e as metas do governo federal para uma rede nacional de organizações ambientais? Estabelecer sistemas formais para o envolvimento público deverá ser menos bem-sucedido que a evolução de padrões do interesse público em participar da escolha das metas e no acompanhamento e avaliação da consecução das mesmas.

Mas a ênfase da nova gestão pública em alcançar metas específicas pode ter um efeito importante na atitude do público com respeito ao governo. Pois muito do descontentamento público com o governo pode ser traçado por sua crença (seja justificada ou não) de que ele não ganha muito de seu governo, que o que ele recebe não compensa o dinheiro gasto pelo seu governo, e que seu governo não consegue produzir resultados. Se isso é verdade, então o enfoque nos resultados - e a criação de um sistema de acompanhamento que dramatize os resultados alcançados ou não por diferentes agências pode influenciar a opinião pública. Ao produzir resultados específicos - ao atingir metas específicas e preestabelecidas — as agências públicas podem começar a convencer os cidadãos de que o desempenho do governo não é uma contradição.

\section{A busca de um novo paradigma de accountability democrática}

Ao dar poder aos servidores públicos para que dêem respostas aos cidadãos, ao dar-lhes autoridade para tomar decisões inovadoras, os defensores da nova gestão pública buscam produzir melhores resultados. Mas quais resultados? Quais são os melhores resultados? Quem decide que resultados o governo deve produzir? Quem irá certificar-se de quem responderá pela produção desses resultados? Como irá funcionar esse processo de accountability? Os defensores da nova gestão pública precisam não só demonstrar que sua estratégia de organização do aparato administrativo do governo é mais eficiente ou eficaz. Eles também devem 
explicar como ele tem (ou pode ter) accountability. Eles devem ser capazes de responder a questão da accountability por desempenho:

É possível permitir que servidores com poder (emplowered) e capacidade de resposta, tomem decisões e sejam inovadores e ainda sim contar com accountability democrática?

Eles ainda têm de fazê-lo.

Mas essa não é uma tarefa trivial. Afinal, criar accountability democrática por processo não tem sido fácil. Temos tentado trabalhar nisso por mais de dois séculos, e ainda não produzimos uma resposta totalmente satisfatória. De fato, os mecanismos que estabelecemos para garantir accountability por processo nem sempre funcionam.

Além disso, não iremos responder a questão da accountability por desempenho engajando-nos num profundo pensamento teórico. E mais, ganharemos pouco ao debatermos, legislarmos, codificarmos e equiparmos os sistemas formais de accountability cidadã.

Ao contrário, aprenderemos mais de uma série de experimentos ad hoc conduzidos por gestores públicos que buscam não ser covardes nem fora-da-lei, mais sim cumprir os propósitos públicos que os cidadãos valorizam. Gestores públicos que buscam produzir os resultados que os cidadãos desejam serão os pesquisadores que irão responder a questão da accountability. De fato, a resposta à questão da accountability somente poderá emergir da prática - evoluindo de uma variedade de esforços classistas de novos gestores públicos que não desejam obscurecer sua accountability, mas sim defini-la e esclarecê-la.

Alguns desses experimentos fracassarão. E se houver muitos fracassos, todo o esforço será abandonado. Alguns, no entanto, poderão tornar-se sucessos modestos e qualificados. E sobre tais modestos sucessos os gestores públicos planejarão outros experimentos e produzirão outros sucessos. A tarefa de responder à questão da accountability recai não somente nos ombros dos teóricos da nova gestão pública, mas naqueles dos seus praticantes. À medida que os experimentos estão sendo construídos, no entanto, os teóricos ajudarão a codificar seus fracassos, sucessos e lições.

Por definição, tais experimentos de accountability deverão, de alguma forma, envolver cidadãos. Pois a base conceitual da nova gestão pública é a de que os cidadãos precisam de um melhor desempenho de seu governo. Mas que tipo de desempenho? Cidadãos têm interesse tanto na escolha das metas quanto na consecução delas. Assim, qualquer mecanismo de accountability deve permitir que os cidadãos participem do debate sobre a escolha das metas, e do acompanhamento e avaliação da consecução delas.

Mas como? Serão adequados os sistemas eleitorais existentes? Ou serão necessários mecanismos extra-eleitorais? Se for assim, eles 
serão dominados por stakeholders organizados? Ou serão eles irrelevantes, com os jornalistas continuando a enfocar o processo - especialmente os erros menos importantes no cumprimento das regras e dos procedimentos? Ou será de alguma forma possível engajar o interesse do Estado nas metas que seus municípios estabeleceram para seu sistema escolar, as metas que seus estados estabeleceram para suas agências de apoio a famílias, e as metas que o governo federal estabeleceu para a rede nacional de organizações ambientais?

Se for assim, quando serão os cidadãos envolvidos na escolha das metas e no acompanhamento e avaliação de sua consecução? Em que tipo de resultados e desempenho estarão os cidadãos mais interessados? Como eles preferirão engajar-se no desafio de escolher, acompanhar e avaliar? Como preferirão conhecer suas escolhas, os dados? Como poderão estar engajados, mas não excessivamente? Essas são questões operacionais importantes que os experimentos com os novos mecanismos de accountability irão colocar. As respostas só irão emergir quando os experimentos evoluírem.

Os sistemas tradicionais de accountability foram desenhados para estabelecer e reforçar a confiança pública na probidade de seu governo. Agora precisamos de um novo sistema de accountability que estabeleça e reforce a confiança pública no desempenho governamental. O paradigma da nova gestão pública exige um novo paradigma de accountability democrática.

\section{Notas}

1 Existem numerosas concepções do paradigma da nova gestão pública. Para a descrição de algumas, ver: Barzelay (1992), Osborne e Gaebler (1992), Gore (1993), Borins (1995a; 1995b), Public Management Service (OECD: 1995; 1996) e Thompson 1997. Borins oferece a seguinte definição: "a nova gestão pública é uma nova conceituação da administração pública que consiste de vários componentes inter-relacionados: fornecer serviços de alta qualidade que os cidadãos valorizam; aumentar a autonomia dos gestores públicos, especialmente dos controles da agência central; medir e premiar organizações e indivíduos com base no cumprimento das metas exigidas de performance; tornar disponível recursos humanos e tecnológicos que os gestores necessitam para desempenharem bem suas tarefas; e, reconhecendo as virtudes da competição, manter uma atitude aberta a respeito de quais propósitos públicos devem ser desempenhados pelo setor privado, e não pelo setor público" (1995a: 122). 
2 Existem várias defesas do paradigma tradicional da administração pública (assim como críticas à nova gestão pública). Para algumas, ver: Frederickson (1992), Moe (1994), Moe e Gilmour (1995) e Savoie (1995a; 1995b)

3 Eles podem não acreditar numa "maneira melhor" porque aceitam que a melhor prática de amanhã pode ser melhor do que a de hoje.

4 Embora eles nunca tenham trabalhado juntos, Wilson, Taylor e Weber foram da mesma geração. Wilson e Taylor nasceram em 1856, Weber em 1864. Portanto, não chega a ser surpreendente que suas crenças e recomendações sobre administração sejam tão compatíveis. Eles não estavam somente moldando as opiniões da nação; estavam também relatando-as. Não estavam somente criando idéias; também suas idéias refletiam a cultura e as necessidades daqueles tempos. Como Fry observou a respeito da gestão científica de Taylor, era "claramente um movimento correto para seu tempo" (1989: 68). Em muitos aspectos, Wilson, Taylor e Weber não lideraram o pensamento de sua época da mesma maneira que o refletiam.

Os escritos de Wilson, por exemplo, previram tanto a gestão científica de Taylor quanto a defesa de Goodnow da separação entre política e administração. Wilson pode ter sido o primeiro a sugerir numa publicação que a implementação da política precisava ser separada de sua criação, mas ele não estava sozinho. De fato, embora Wilson tenha tornado-se ativamente engajado na política americana, seu ensaio sobre 'O Estudo da Administração' (1887) foi pouco conhecido durante décadas. Muito mais influente no estabelecimento da dicotomia política - administração foi o livro de Frank Goodnow, Política e Administração, publicado 13 anos mais tarde (1900).

Em seu ensaio, Wilson também defendia a criação de uma ciência da administração, mas foi Taylor quem não só realizou tal tarefa, como também convenceu o país de sua utilidade. De fato, dos três, somente Taylor buscou, agressivamente, convencer o público americano do valor de suas idéias a respeito da administração.

E o pensamento de Weber não estava facilmente disponível nos Estados Unidos até depois da Segunda Guerra, quando Hans H. Gerth e C. Wright Mills traduziram e publicaram uma coleção dos escritos de Weber (1946) e A.M. Henderson e Talcott Parsons fizeram o mesmo (1947). No entanto, isso não evitou que empresas e governos americanos criassem grandes burocracias, muito similares às que Weber defendia. Quando o governo cria conscientemente uma política que foi desenhada para tratar as pessoas de forma diferente - por exemplo, ação afirmativa — é difícil avaliar a justiça da implementação. Assim, tanto a política quanto a implementação serão acusadas de serem injustas.

6 Alguns acreditam que essa accountability direta não é suficientemente direta. Assim criaram a iniciativa e o referendo, para o caso de nossos representantes não estabelecerem as políticas que realmente desejamos.

7 No entanto, embora Wilson tenha anunciado que sua distinção era "tão óbvia que dispensava maiores discussões", ele também confessou que ela não era tão exatamente óbvia até que se olhasse para as particularidades do tema político em particular: "Uma pessoa não pode facilmente tornar claro para todos onde reside a administração de vários departamentos de qualquer governo praticamente sem entrar nos particulares tão numerosos ao ponto de confundir-se, e nas distinções tão detalhadas ao ponto de distrair-se. Nenhuma linha de demarcação, separando funções administrativas e não-administrativas, pode ser traçada entre este e aquele departamento do governo sem dar voltas e mais voltas entre as curvas da distinção e através das densas selvas de legislação estatutária; vaguear entre os vários 'se' e 'porém', 'quando' e 'entretanto', até que fiquem todos perdidos no olhar comum e desacostumado com 
esse tipo de pesquisa, e conseqüentemente pouco familiarizado com o uso do teodolito do discernimento lógico" (1887: 18-9).

Desse modo, escreve Thorsen: "Wilson explicitamente via a separação entre administração e política como um assunto prático a ser estabelecido quando questões concretas surgissem no curso da mudança das funções e técnicas governamentais" (1988: 119).

8 Taylor acreditava, reporta Fry, "que todo homem é um trabalhador 'de $1^{\mathrm{a}}$ classe' em algum tipo de trabalho". Assim, era também responsabilidade da gerência determinar o trabalho para o qual cada trabalhador estaria mais qualificado (1989: 53-4).

9 N.T.: É um documento que detalha as tarefas específicas de um posto, e determina quanto tempo cada tarefa ocupa na rotina de trabalho do funcionário, o nível de responsabilidade e independência, o impacto do erro e do trabalho executado com qualidade no conjunto de tarefas desempenhadas em uma instituição.

10 Weber via as burocracias privadas e públicas como essencialmente similares: "A idéia de que as atividades de gabinete do Estado são de caráter intrinsecamente diferente da gestão dos escritórios da economia privada é uma noção da Europa continental e, dessa forma, totalmente estranha à maneira americana".

11 Em outra parte (Behn, 1997: 17), perguntei o que realmente significa exigir accountability do governo: O que realmente queremos quando tornamos uma organização responsável por algo? De várias formas, isso significa que queremos ser capazes de identificar quem é responsável pelos produtos da organização, por seus sucessos ou fracassos. Mas o que acontece depois? Essa pergunta não traz muita clareza aos fatos. O que significa tornar as pessoas responsáveis pelo sucesso? O que significa tornar as pessoas responsáveis pelo fracasso?

Desconheço a resposta definitiva, seja teórica ou empírica. Mas aposto que sei o que os gerentes que devem possuir a accountability pensam. Aposto que eles acreditam, pela própria experiência empírica, que 'cobrar accountability das pessoas' significa que se elas fracassam, elas são punidas, e se elas têm sucesso, nada de significativo acontece.

12 Borins afirma: "em áreas onde exige-se coordenação, tem-se tornado cada vez mais evidente que a coordenação informal e as parcerias são uma alternativa melhor que a coordenação central" (1995: 125).

13 Para uma discussão sobre accountability dentro de redes — ou dentro do que chamam collaboratives - ver Bardach e Lesser (1996).

14 Altshuler afirma que autoridades eleitas têm pouco incentivo para engajar-se no controle de agências públicas — que há muitas formas mais úteis para elas gastarem seu tempo (1997).

15 Realmente, isso é o que os defensores do liberalismo dos grupos de interesse têm feito — tentado dar uma boa aparência à realidade.

16 Defensores organizados irão preferir políticas que concentrem os benefícios neles e, para evitar a mobilização da oposição, que cada um esconda ou disfarce os custos. Se os defensores do paradigma da nova gestão pública querem prender a atenção do governo nos resultados, eles necessitarão definir quem exatamente será responsável pela implementação de um processo de accountability enfocado não somente no alcance daqueles resultados específicos, mas também na consecução de tais resultados de forma que seja eficiente no uso direto dos recursos públicos e não imponha outros custos indiretos.

17 Nos últimos anos, organizações políticas, que se preocupam muito com uma única política pública, têm sido capazes de utilizar de maneira bastante eficiente o processo tradicional de accountability nas eleições. Elas têm ignorado o conjunto das políticas, escolhem candidatos com base na sua posição sobre um tema mais importante, e então lança para eleger aqueles com quem concordam e combate os outros com quem 
têm diferenças. Ainda assim, tais organizações monotemáticas são denunciadas como uma perversão do processo democrático.

18 Se ela fracassa em tornar claras suas discordâncias em um número seleto de temas sejam eles importantes ou não - a oposição terá dificuldade em explicar ao eleitorado porque ela deveria substituir o partido no poder.

19 Obviamente, alguns cozinheiros estão bastantes felizes por não receberem nenhum poder discricionário quanto à gerência do forno e do fogão. Pois sem esse poder, pode haver total falta de responsabilidade. É por isso que tantos cozinheiros — e também muitos gerentes de segundo escalão e trabalhadores de linha de frente - recusam-se a ter mais poder. Pois capacitar pessoas significa dar-lhes responsabilidade. O medo da capacitação é o medo da responsabilidade.

20 Nossa! Há 110 anos, Woodrow Wilson resumiu sucintamente o problema do principal-agente.

21 Quando o Senador William Proxmire dedicava mensalmente seu Prêmio Golden Fleece a agências públicas que desperdiçassem dinheiro dos contribuintes, ele descobriu que tinha obtido mais atenção ao premiar exemplos pequenos e compreensíveis de desperdício do Governo do que aqueles grandes e complicados (Behn, 1991a: 114).

22 Claro que há várias razões para que os gestores públicos evitem determinar metas específicas, incluindo o próprio medo da responsabilidade.

23 Foi o caso do Departamento de Bem-Estar Público de Massachusetts no meio da década de 80. O Departamento tinha 10 metas, e as respectivas unidades de cada divisão tinham suas próprias metas (Behn, 1991a: cap. 4).

24 Essa sugestão não resolve o problema da rede; tampouco elimina o anonimato dos vários componentes da rede. Mas poderia. Caso uma rede aceitasse a responsabilidade por um dado programa ou política, ela poderia também ser solicitada a criar uma meta específica a ser alcançada até o final do ano fiscal. Nesse momento, ela poderia solicitar que cada componente da rede criasse sua própria meta para o ano fiscal. A seguir, caso a rede falhasse na consecução da meta, essa rede de metas destacaria a responsabilidade - tanto do componente individual da rede que teria falhado na consecução de suas metas, quanto na liderança da rede que teria falhado em criar uma rede de metas cuja consecução resultaria automaticamente na realização da meta geral da rede. Mas antes de tentarmos usar metas subordinadas para destacar a responsabilidade e aumentar a accountability dentro das redes, deveríamos verificar se podemos fazê-las funcionar dentro de organizações mais hierarquizadas. Para uma discussão sobre accountability em redes (ou, como são chamadas, collaboratives), ver Bardach e Lesser (1996).

\section{Referências bibliográficas}

Altshuler, Alan A.. (1997) "Bureaucratic Innovation, Democratic Accountability, and Political Incentives", In Alan A. Altshuler e Robert D. Behn (eds.), Innovation in American Government. Washington, D.C.: The Brookings Institution, p. 38-67.

BARDACH, Eugene e LeSSER Cara. (1996), "Accountability in Human Services Collaboratives? For What? and To Whom?". Journal of Public Administration Research and Theory, v. 6, n. 2, abril, p. 197-224. 
BeHn, Robert D.. (1991 a), Leadership Counts: Lessons for Public Managers. Cambridge,

Mass.: Ed. Harvard University.

. (1991b), "Innovation and Public Values: Mistakes, Flexibility,

Purpose, Equity, Cost Control and Trust." Paper apresentado na conferência "Questões Fundamentais da Inovação", Duke University, 4 de maio.

(1995), "The Big Questions of Public Management". Public

Administration Review, v. 55, n. 4 , Julho/Agosto p. 313-24.

. (1996), "Public Management: Should It Strive to be Art, Science,

or Engineering?". Journal of Public Administration Research and Theory, v. 6, n 1, janeiro p. 91-123.

. (1997), "Linking Measurement and Motivation: A Challenge for

Education". Advances in Educational Administration, v. 5, p. 15-58.

Bendix, Reinhard. (1960), Max Weber: An Intellectual Portrait. Berkeley: Editora University of California Ed.

Borins, Sanford. (1995a), "The new public management is here to stay". Canadian Public Administration, v. 38, n 1,Spring, p. 122-132.

. (1995b), "A last word". Canadian Public Administration, v. 38, n 1, Spring, p. 137-138.

Duncan, W. Jack. (1989), Great Ideas in Management: Lessons from the Founders and Foundations of Managerial Practice. San Francisco: Jossey-Bass Eds.

FrederICKSON, H. George. (1992), "Painting Bull's Eyes Around Bullet Holes". Governing, v. 6, december, p. 61.

Fry, Brian. (1989), Mastering Public Administration: From Max Weber to Dwight Waldo. Chatham, N.J.: Chatham House Eds.

Gerth, Hans H.. e Wright Mills, C. (eds.). (1946), From Max Weber: Essays in Sociology. New York: Oxford University Ed..

Goodnow, Frank J.. (1990), "Politics and Administration", Politics and Administration: A study in Government. New York: Russell \& Russell, p. 17-26. Reimpresso em Classics of Public Administration, Jay M. Shafritz e Albert C. Hyde (eds.), 3ª edição Pacific Grove, Calif.: Brooks / Cole Co, Eds., p. 25-8.

GoRe, Albert. (1993), From red Tape to Results: Creating a Government that Works Better and Costs Less (Report of the National Performance Review). Washington, D.C.: Gabinete de Imprensa do Governo Americano.

MoE, Ronald C.. (1994), “The 'Reinventing Government' Exercise: Misinterpreting the Problem, Misjudging the Consequences". Public Administration Review, v. 54, n. 2 mar/apr, p. 111-122.

Moe, Ronald C. e Gilmour Robert S.. (1995), "Rediscovering Principles of Public Administration: The Neglected Foundation of Public Law". Public Administration Review, v. 54, n 2 mar/apr, p. 135-146.

Moore, Mark H.. (1993), Accounting for Change: Reconciling the Demands for Accountability and Innovation in the Public Sector. Washington, D.C.: Council for Excellence in Government.

Public Management Service. (1995), Governance in Transition: Public Management Reforms in OECD Countries. Paris: Organização para a Cooperação e o Desenvolvimento Econômico.

. (1996), Responsive Government: Service Quality Initiatives. Paris:

Organização para a Cooperação e o Desenvolvimento Econômico.

SAvore, Donald J.. (1995 a), "What is wrong with the new public management?". Canadian Public Administration, v. 38, n 1 Spring, p. 112-121. 
Administration, v. 38, n 1, Spring, p. 133-136.

TAYLOR, Frederick Winslow. (1991), The Principles of Scientific Management. New York: Harper and Brothers. Reimpresso em 1997. W.W. Norton \& Company.

Thompson, Fred. (1997), "The New Public Management: Book Review Essay". Journal of Policy Analysis and Management, v. 16, n. 1, Winter, p. 165-176.

Thorsen, Niels Aage. (1988), The Political Thought of Woodrow Wilson: 1875-1910. Princeton, N.J.: Princeton University Press.

United States Senate, Committee on Governamental Affairs. (1993), Government Performance and Results Act, Report 103-58, June 16. Washington, D.C.: U.S. Government Printing Office.

Weber, Max. (1947), The Theory of Social and Economic Organization (A. M. Henderson traduzido por Talcott Parsons). Glencoe, III.: The Free Press.

WiLson, Woodrow. (1887). “The Study of Administration”. Political Science Quarterly, 2. Reimpresso em Classics of Public Administration, 3 ed., Jay M. Shafritz and Albert C. Hyde (eds.). Pacific Grove, Calif.: Brooks/Cole Publishing Co., p. 11-24.

Wrege, Charles D., Greenwood, Ronald G. (1991), Frederick W. Taylor, The Father of Scientific Management: Myth and Reality. Homewood, III.: Business One Irwin.

Zegans, Marc D.. (1997), "The Dilemma of the Modern Public Manager: Satisfying the Virtues of Scientific and Innovative Management", in Alan A Alshuler and Robert D. Behn (eds.) Innovation in American Government, Washington, D.C.: The Brookings Institution, p. 104-118. 


\section{accountability democrática}

\section{Robert Behn}

$\mathrm{O}$ artigo aborda as questões ligadas ao tema da accountability dentro do paradigma da nova gestão pública: é possível permitir que servidores públicos, investidos de poder e prontos para responder aos problemas, tomem decisões e sejam inovadores, e ainda assim tenham accountability democrática? Essa importante questão ${ }^{1}$ tem assombrado aqueles que defendem uma 'nova gestão pública'. Os proponentes do paradigma da nova gestão pública enfatizam a capacidade de sua estratégia de produzir resultados. No entanto, eles ignoram a problemática questão da accountability política. Eles deverão desenvolver um processo que não só permita aos gestores públicos alcançar melhores resultados, mas também garantir a accountability perante um eleitorado democrático.

\section{EI Nuevo paradigma de la Gestión Pública y la búsqueda de la accoutability democrática}

Robert Behn

El artículo aborda las cuestiones relativas al tema de la accoutability democrática dentro del paradigma de la nueva gestión pública. Se pregunta: ¿es posible permitir que empleados públicos, investidos de poder y listos para responder a los problemas, tomen decisiones y sean innovadores, y que todavía tengan accoutability democrática? Ese importante cuestionamiento ha asombrado a aquellos que defienden una nueva gestión pública. Los que proponen el paradigma de la nueva gestión pública dan énfasis a la capacidad de su estrategia en producir resultados. No obstante, ignoran la problemática cuestión de la accoutability política. Ellos deberán desarrollar un proceso, el cual no solamente, les permita a los gestores públicos alcanzar mejores resultados, sino que también, garantizar la accoutability ante un electorado democrático.

\section{The New Public-Management Paradigm And The Search For Democratic Accountability}

\section{Robert D. Behn}

Can we permit empowered, responsive civil servants to make decisions and be innovative and still have democratic accountability? This important question haunts those who would advocate a "new public management." The proponents of a new public-management paradigm emphasize performance the ability of their strategy to produce results. But they cannot ignore the troubling question of political accountability. They must develop a process that not only permits public managers to produce better results but also provides accountability to a democratic electorate. 